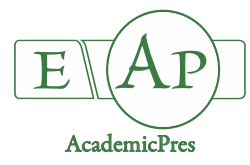

\title{
Combining Ability for Yield of Single-Cross Hybrids Derived from Maize Composites (Zea mays L.)
}

\author{
Andreea D. ONA ${ }^{1}$, Leon MUNTEAN ${ }^{1 *}$, Voichița V. HAȘ ${ }^{2}$, Andrei VARGA ${ }^{2}$ \\ ${ }^{1}$ University of Agricultural Sciences and Veterinary Medicine, Faculty of Agriculture, Department of Plant Culture, 3-5 Calea Mănăstur, \\ 400372 Cluj-Napoca, Romania; andreea.ona@gmail.com; leon.muntean@usamvcluj.ro ("correspondingauthor) \\ ${ }^{2}$ Agricultural Research and Development Station Turda, 27 Agriculturii, Turda, \\ Romania; hasvoichita@yahoo.com; andrei_varga06@yahoo.com
}

\begin{abstract}
Development of high-yielding hybrids of maize depends on good understanding of combining ability and inheritance of yield trait. To achieve this goal, synthetic populations of lines are developed and improved upon by recurrent selection to be utilized as initial material for the creation of inbred lines. Therefore, the aims of the present paper were: to determine the combining ability among some inbred lines developed from composites and commercial hybrids by recurrent selection method and to choose the most promising inbreds for maize yield improvement and the most suitable hybrid combinations. The highest value of the general combining ability (GCA) was obtain from inbred line TA $447\left(1,655 \mathrm{~kg} \mathrm{ha}^{-1}\right)$ followed by tester TC $399\left(233 \mathrm{~kg} \mathrm{ha}^{-1}\right)$. For the specific combining ability (SCA), TA $447 \times$ TC 385 A, TA $427 \times$ TC 399, TA $428 \times$ TC 399 and CO $305 \times$ TD 268 had good compatibility. The research concluded that GCA was more important that SCA, indicating that the additive genetic effects are mainly involved in the heredity of yield potential of maize. For the non-additive effects to increase, the next selection cycles must focus on plants' pairs with more pronounced heterosis for the yield trait.
\end{abstract}

Keywords: composites; general and specific combining ability; inbred lines; maize; yield

\section{Introduction}

Potential for high maize yield, though it is most complex feature (Sarca, 2004), is the main aim of breeding programs because it makes the greatest contribution to the economic efficiency of a culture. To achieve this, the entire genetic system of the plant acts through its mechanisms on a large number of physically, chemically, biologically, physiologically and biochemically interrelated processes (Sarca, 2004). Increasing yield potential is a combination of genetics and management practices (Hmielowski, 2018). Development of high-yielding hybrids depends on good understanding of combining ability and inheritance of important quantitative traits such as grain yield (Owusu et al., 2017), as well as good choice of the proper inbred lines. According to Hallauer (1990) production potential can only be identified by testing the combining capacity of inbred lines. "The objective of the maize breeder should thus not be to find the best pure line, but to find and maintain the best hybrid combination" (Hallauer, 1988). Quantitative genetic traits, such as yield, are characterized by cumulative actions of many factors which include gene effects and effects due to the interaction of genotype and environment (Djemel et al., 2012). Gene effects represent a big interest for plant breeders in order to formulate the most advantageous breeding procedures for improvement of the yield (Gamble, 1961). According to Bauman (1981) a way to improve yield potential is to develop synthetic populations of lines and to improve them by recurrent selection for using them as the initial material for the creation of inbred lines. Based on the information presented above, the aims of the present paper are (i) to estimate the combining ability of some inbred lines developed by recurrent selection method, (ii) to single-out the most promising inbreds that can be used for improving maize yield, and (iii) to determine the most suitable hybrid combinations.

\section{Materials and Methods}

\section{Experimental environment}

The experiments were conducted at Agricultural Research and Development Station Turda, Romania. The Research Station is located on Transylvanian Plateau in Romania, with the following coordinates: $46^{\circ} 35^{\prime} \mathrm{N}$ latitude, $23^{\circ} 47^{\prime} \mathrm{E}$ longitude, 345-493 $\mathrm{m}$ altitude. Climatic 
466

conditions are presented in Table 1. Type of predominant soil was Luvic Chernozems (CH lv) (WRB-SR-19981, World reference base for soil resources, 2014) ${ }^{1}$. Seeds were sown using a density of 60,000 plants ha $^{-1}$ in a non-irrigated system.

\section{Genetic materials}

The present research was carried out over two experimental years (2011 and 2012) using 24 single-cross hybrids (21 experimental hybrids and 3 controls). The hybrids were developed through crosses between inbred lines derived from composites populations ('Tu Comp A' and 'Tu Comp B') developed from BSSS and Lancaster Sure Crop germplasm group and from other commercial hybrids (details in Table 2). The crosses were performed at Agricultural Research and Development Station Turda on 2010 .

\section{Data analysis}

An important aim in breeding programs is to gain knowledge about the genetic factors controlling maize yield and other important characters (Hallauer et al., 2012), thus we employed Analysis of Variance (ANOVA) which allows simultaneously study of the variability due to every factor involved in the yield potential of maize. The variance of genotypes was splited into influence of testers, inbred lines and interactions, using the model described by Has et al. (2010). Genetic effects were calculate using $2^{\text {nd }}$ "North
Carolina" model (Căbulea, 2004). Grain yield of every hybrid from experimental system was calculated after the formula:

$$
S H_{m \times n} \text { yield }=\mu+\hat{g}_{m}+\hat{g}_{n}+\hat{s}_{m \times n}
$$

where: $\mu=$ average yield of experimental hybrids; $\hat{\mathrm{g}}_{\mathrm{m}}=$ additive effects due parent $\mathrm{m} ; \hat{\mathrm{g}}_{\mathrm{n}}=$ the additive effects due parent $\mathrm{n} ; \hat{\mathrm{s}}_{\mathrm{mxn}}=$ non-additive effects due to $\mathrm{m} \times \mathrm{n}$ crossing. Correlations, regressions and determination coefficients in the classical way were computed to connect the additive and non-additive genetic effects with yield potential.

\section{Results}

Highly significant years $\left(2,533.90^{* *}\right)$, genotypes $\left(16.38^{* *}\right)$, single-cross hybrids $\left(17.71^{* *}\right)$ and additive actions $\left(51.62^{* *}\right)$, and significant comparisons SC-H - CH $\left(18.18^{* *}\right)$ was noted for the yield potential.

The contribution of testers, tested inbred lines and interactions to the total variance had been presented in Fig. 1. The variance of tested inbred lines had the highest value on total variance of yield and variance, due interaction was the lowest.

Analyzing the variability of testers (Table 4), the TC 399 tester was remarked for the general combining ability. The tester lines still need genes accumulations with additive and dominant effects for the more pronounced GCA expression. Among the inbred lines tested for the general combining ability, highly significant differences (***) presented the line TA 447.

Table 1. Rainfalls and average air temperature during the 2011 and 2012 growing seasons

\begin{tabular}{|c|c|c|c|c|c|c|}
\hline \multirow{2}{*}{ Month } & \multicolumn{3}{|c|}{ Rainfalls (mm) } & \multicolumn{3}{|c|}{ Average temperature $\left({ }^{\circ} \mathrm{C}\right)$} \\
\hline & 2011 & 2012 & Average on 50 years & 2011 & 2012 & Average on 50 years \\
\hline April & 22.6 & 78.4 & 46.1 & 10.7 & 11.8 & 9.8 \\
\hline May & 41.4 & 89.2 & 67.4 & 15.6 & 16.2 & 14.8 \\
\hline June & 116.8 & 67.4 & 80.6 & 19.2 & 21.0 & 17.8 \\
\hline July & 130.4 & 52.4 & 74.7 & 20.1 & 24.0 & 19.5 \\
\hline August & 12.8 & 28.0 & 57.0 & 20.8 & 22.3 & 19.4 \\
\hline September & 22.8 & 30.2 & 40.0 & 18.2 & 19.1 & 14.9 \\
\hline
\end{tabular}

Table 2. Testers, tested inbred lines and control hybrids used in the experimental system

\begin{tabular}{|c|c|c|}
\hline Name & Origin & Owner \\
\hline \multicolumn{3}{|c|}{ Tested Inbred Lines } \\
\hline TA 447 & Sel. from commercial hybrid & ARDS Turda \\
\hline $\mathrm{CO} 305$ & Sel. from $(\mathrm{CO} 258 \times \mathrm{CO} 255) \mathrm{CO} 255$ & ARDS Turda \\
\hline TA 428 & Sel. from 'Comp A' & ARDS Turda \\
\hline TA 425 & Sel. from 'Comp A' & ARDS Turda \\
\hline TA 427 & Sel. from 'Comp A' & ARDS Turda \\
\hline PT 1932 & Sel. from 'Porumbeni' & ARDS Turda \\
\hline PT O27 & Sel. from 'Porumbeni' & ARDS Turda \\
\hline \multicolumn{3}{|c|}{ Tester Inbred Lines } \\
\hline TD 268 & Sel. din TC208 × C103 & ARDS Turda \\
\hline TC $385 \mathrm{~A}$ & Sel. from ‘Comp B’ & ARDS Turda \\
\hline TC 399 & Sel. from 'Comp B' & ARDS Turda \\
\hline \multicolumn{3}{|c|}{ Control Hybrids } \\
\hline 'Turda 201' & \multicolumn{2}{|c|}{ ARDS Turda } \\
\hline ‘Turda Favorit’ & \multicolumn{2}{|c|}{ ARDS Turda } \\
\hline 'PR39 D81' & \multicolumn{2}{|c|}{ Pioneer } \\
\hline
\end{tabular}


Yield potential of simple hybrids ranged from 7 to 10.31 tons $\mathrm{ha}^{-1}$. Specific combining ability touched values enclosed by -303 and $334 \mathrm{~kg} \mathrm{ha}^{-1}$.

The regression line, the regression equation (y), the correlation coefficient $(\mathrm{r})$ and the determination coefficient $\left(\mathrm{R}^{2}\right)$ for the studied crossing system and for the correlations of additive and non-additive genetic effects and maize yield are presented in Figs. 2 and 3. The correlation coefficient $(\mathrm{r})$ indicates a strong relation between yield and the sum of additive effects; $r$ was distinctly significant different from zero $\left.{ }^{* *}\right)$ and the value of $\mathrm{R}^{2}$ denote that the sum of additive effects strongly influences yield's gain: for every $100 \mathrm{~kg} \mathrm{ha}^{-1}$ growth of additive effects, maize yield grew with $95 \mathrm{~kg}$.

The correlation between non-additive genetic effects and yield was not statistically significant (Fig.3). The bond between the two variables was lower than the sum of additive genetic effects indicating through determination coefficient less dependence of maize yield on non-additive genetic effects.

Table 3. ANOVA for yield potential on the experimental cross system

\begin{tabular}{|c|c|c|c|c|c|c|}
\hline \multirow{2}{*}{ Variability cause } & \multirow{2}{*}{ Sum of squares } & \multirow{2}{*}{ DF } & \multirow{2}{*}{$s^{2}$} & \multicolumn{2}{|c|}{ F test according to } & \multirow{2}{*}{ Signif. } \\
\hline & & & & error & $\mathrm{Y} \times \mathrm{G}$ & \\
\hline Total & $756,411,079.00$ & 239 & & & & \\
\hline Repetitions & $2,731,612.00$ & 4 & & & & \\
\hline Years & $597,704,704.00$ & 1 & $597,704,704.00$ & $2,533.90$ & 619.03 & ** \\
\hline Error $(\mathrm{Y})$ & $1,517,922.00$ & 4 & & & & \\
\hline Genotypes $(\mathrm{G})$ & $88,846,526.00$ & 23 & $3,862,892.00$ & 16.38 & 4.00 & ** \\
\hline Single-cross hybrids (SC-H) & $83,560,069.30$ & 20 & $4,178,003.47$ & 17.71 & 4.33 & ** \\
\hline Tester additive actions & $6,497,034.97$ & 2 & $3,248,517.48$ & 13.77 & 3.36 & \\
\hline Tested lines additive actions & $73,055,333.75$ & 6 & $12,175,888.96$ & 51.62 & 12.61 & ** \\
\hline Non-additive interactions & $4,007,700.59$ & 12 & $333,975.05$ & 1.42 & 0.35 & \\
\hline Control hybrids $(\mathrm{CH})$ & $998,747.44$ & 2 & $499,373.72$ & 2.12 & 0.52 & \\
\hline Comparisons (SC-H - CH) & $4,287,709.25$ & 1 & $4,287,709.25$ & 18.18 & 4.44 & * \\
\hline Years $\times$ Genotypes $(\mathrm{Y} \times \mathrm{G})$ & $22,207,764.00$ & 23 & $965,554.90$ & 4.09 & & \\
\hline Error $^{1}$ & $43,402,551.00$ & 184 & $235,883.40$ & & & \\
\hline
\end{tabular}

Table 4. Grains yield, additive and non-additive effects for the maize inbred lines from the experimental cross system

\begin{tabular}{|c|c|c|c|c|c|c|c|c|c|}
\hline \multirow{2}{*}{\multicolumn{2}{|c|}{$\begin{array}{c}\text { Tester } \\
\text { Tested line }\end{array}$}} & \multicolumn{2}{|c|}{ TD 268} & \multicolumn{2}{|c|}{ TC $385 \mathrm{~A}$} & \multicolumn{2}{|c|}{ TC 399} & \multicolumn{2}{|c|}{ Tested line } \\
\hline & & $\mathrm{kg} \mathrm{ha}^{-1}$ & $\hat{S}_{\operatorname{mxn}}$ & $\mathrm{kg} \mathrm{ha}^{-1}$ & $\hat{s}_{\operatorname{mxn}}$ & $\mathrm{kg} \mathrm{ha}^{-1}$ & $\hat{s}_{\mathrm{mxn}}$ & Avg & $\hat{\mathrm{g}}_{\mathrm{m}}$ \\
\hline & TA 447 & 9,303 & -291 & 10,309 & 334 & 10,092 & -43 & $9,901^{* * *}$ & 1,655 \\
\hline & CO 305 & 8,077 & 234 & 8,106 & -120 & 8,271 & -114 & 8,151 & -95 \\
\hline & TA 428 & 6,985 & 62 & 7,003 & -303 & 7,705 & 241 & 7,231 & $-1,015$ \\
\hline & TA 425 & 7,677 & -79 & 8,206 & 68 & 8,309 & 11 & 8,064 & -182 \\
\hline & TA 427 & 7,367 & -96 & 7,675 & -170 & 8,270 & 266 & 7,771 & -476 \\
\hline & PT 1932 & 8,093 & 15 & 8,617 & 156 & 8,449 & -171 & 8,386 & 140 \\
\hline & PT O27 & 8,067 & 155 & 8,329 & 35 & 8,263 & -190 & 8,219 & -27 \\
\hline \multirow{3}{*}{ Tester } & Avg & 7,939 & & 8,321 & & 8,480 & & 8,246 & \\
\hline & $\hat{\mathrm{g}}_{\mathrm{n}}$ & & -308 & & 74 & & 233 & & \\
\hline & LSD & & & $=552 \mathrm{~kg}$ & & $29 \mathrm{~kg} \mathrm{ha}^{-1}$ & P $0.1 \%$ & $\mathrm{ha}^{-1}$ & \\
\hline
\end{tabular}

Note: Avg: average yield; $\hat{\mathrm{g}}_{\mathrm{m},} \hat{\mathrm{g}}_{\mathrm{n}}$ : additive genetic effects; Ŝmxn: non-additive genetic effects; LSD: least significant differences for the experimental trials; P (5\%, 1\%, 0.01\%): probability level

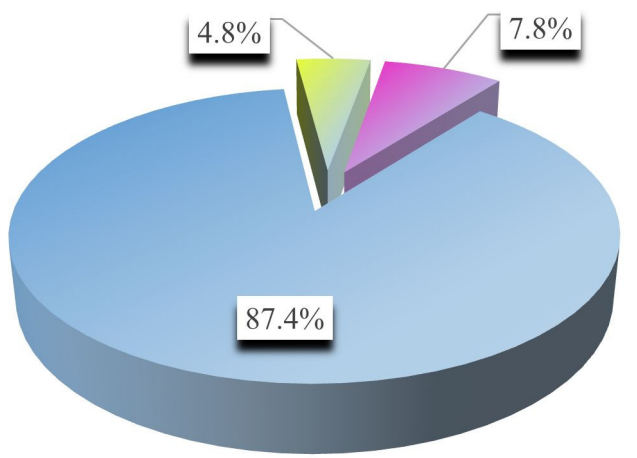

$\varpi$ Testers $\mathrm{T} \square$ Tested lines TL $\square \mathrm{T}$ X TL Interactions

Fig. 1. Contribution of different types of variance on total variance of the yield 


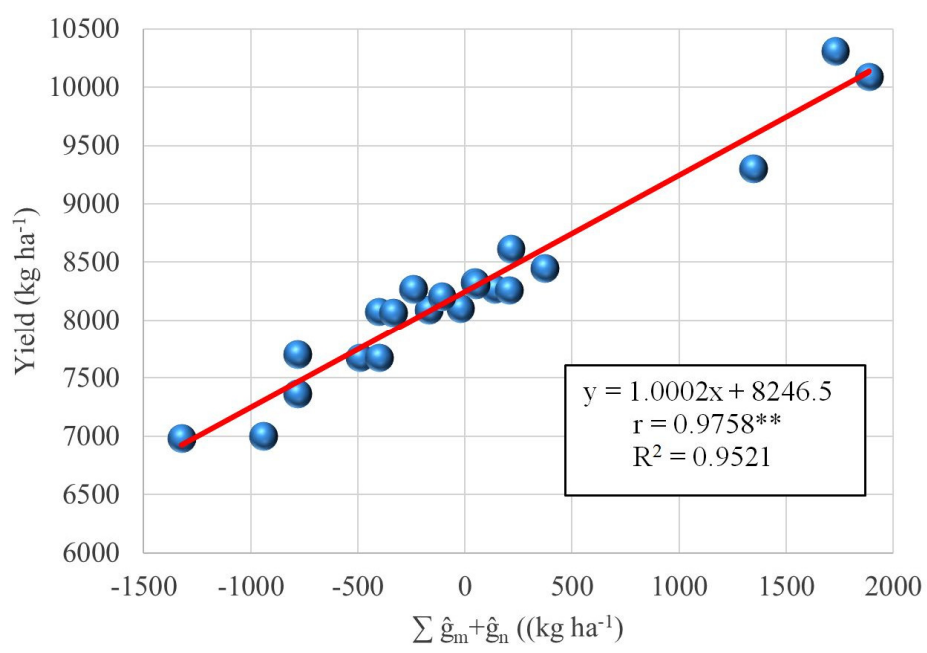

Fig. 2. Regression line and equation for grains' yield according to general combining ability effects $\left(\sum \hat{\mathrm{g}}_{\mathrm{m}}+\hat{\mathrm{g}}_{\mathrm{n}}\right)$ for the studied experimental cross system

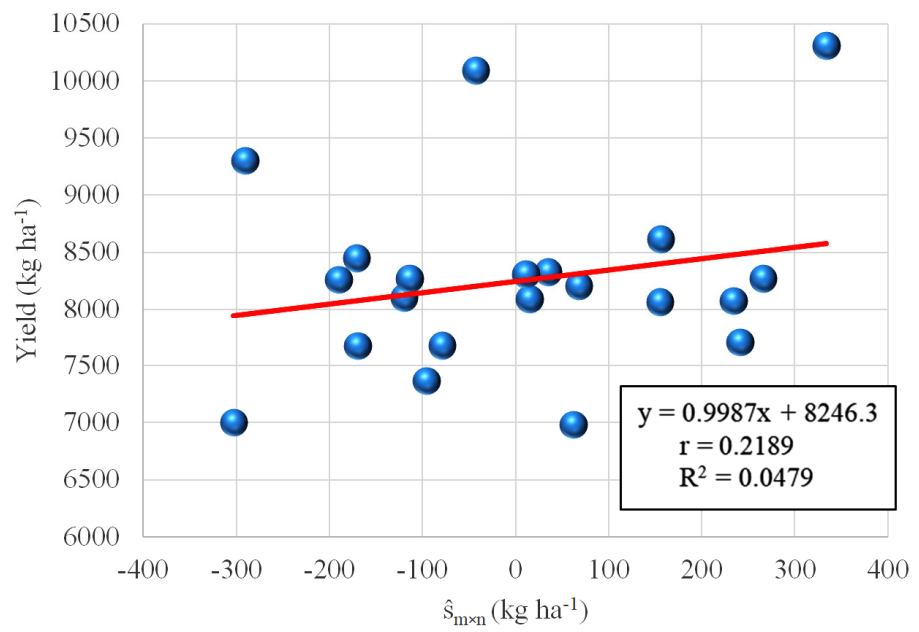

Fig. 3. Regression line and equation for grains' yield according to specific combining ability effects $\left(\hat{\mathrm{s}}_{\mathrm{m} \times \mathrm{n}}\right)$ for the studied experimental cross system

\section{Discussion}

Inbred lines used as parental forms for high-yielding hybrid combinations have to cover two important conditions: good characteristics of the "per se" value of line (very important for maize seed production) and good behaviour in a hybrid combination (Malik et al., 2004). The purpose of a cross between a line and a tester is to identify the superior inbred lines. The general combining ability effects of individual lines are controlled by genes with additive effects and these effects can be passed on to the next generation (Fan et al., 2016). Several authors had earlier concluded that general combining ability is more important than specific combining ability in the inheritance of maize grain yield and other agronomic traits (Malik et al., 2004; Muntean et al., 2014; Ona, 2014; Owusu et al., 2017). The conducted studies of Hallauer et al. (2012) on the importance of genetic effects contribution for gaining yield potential illustrated that the general combining ability was more important than specific combining ability. Anderson et al. (2012) also suggested that the biggest proportion of genetic variation in corn is due to additive genetic effects. Even for tropical and subtropical maize inbred lines, Erdal et al. (2015) concluded that the additive genetic variance is the most important for grain yield. Regarding the contribution of different types of variance on total variance of the yield in the present research, the low variance due to interaction proofed that in the studied inbred lines the contribution of genes with non-additive effect was relatively low compared to the role of additive genetic effects; this situation suggest that for the non-additive effects to increase, the next selection cycles must focus on pairs of plants with more pronounced heterosis for the yield trait. We further concluded from analysis of additive and non-additive genetic effects for the noted hybrids (Table 4), we can conclude that additive gene effects were predominant in producing productive hybrids, both in the case of inbred lines derived from composites and in the case of inbred lines derived from commercial hybrids. Although the association 
between additive genetic effects and maize yield or between non-additive effects and the same trait are weak and less compared to the association between additive effects and production capacity, yet these non-additive genetic effects can differentiate between two performing hybrids. For instance, Souza et al. (2009) concluded that for low and high stress environments, the non-additive genetic effects were the most important for developing a promising hybrid. The same results were also confirmed by Murtadha et al. (2018) who asserted that the hybrids with superior specific combining ability indicate that dominance effects are more effective than additive genetic effects in heredity of some yield elements under low water condition. Finally, we can conclude that if two performing inbred lines with high combining ability for yield are crossed and the non-additive genetic effects between them are high and positive, a new high-yielding hybrid has been found.

\section{Conclusions}

Our research concluded that: (i) the general combining ability was more important than specific combining ability, (ii) the inbred line TA 447 and the tester TC 399 had the highest general combining ability; (iii) for the specific combining ability several hybrid combinations were good combiners: TA $447 \times$ TC 385 A, TA $427 \times$ TC 399 , TA $428 \times$ TC 399 and CO $305 \times$ TD 268; (iv) to increase the role of the non-additive effects, the next selection cycles should focus on the pairs of plants with a more pronounced heterosis for the yield potential.

\section{References}

Anderson AD, Miranda GV, DeLima RO, Goncalves Chaves L, Gomes e Gama EE (2012). Genetic parameters and predictive genetic gain in maize with modified recurrent selection method. Chilean Journal of Agricultural Research 72(1):33-39.

Bauman LF (1981). Review of methods used by breeders to develop superior corn inbreds. Proceedings of the 36th Annual Corn and Sorghum Industry Research Conference. American Seed Trade Association: Washington, DCpp 199-208.

Căbulea I (2004). Genetica porumbului. In: Porumbul - studiu monografic [Maize genetics. In: Maize - Monografic Study]. Ed. Academiei Române, Bucureștipp 207-295.

Djemel A, Ordas B, Khelifi L, Ordas A, Revilla P (2012). Genetic effects on fitness of the mutant sugaryl in wild-type maize. The Journal of Agricultural Science 150(5):603-609.

Erdal S, Pamukcu M, Ozturk A, Aydinsakir K, Soylu S (2015). Combining abilities on grain yield and yield related traits in relation to drought tolerance in temperate maize breeding. Turkish Journal of Field Crops 20(2):203-212.

Fan XM, Yin XF, Zhang YD, Bi YQ, Liu L, Chen HM, Kang MS (2016). Combining ability estimation for grain yield of maize exotic germplasm using testers from three heterotic groups. Crop Science 56:2527-2535.
Gamble EE (1961). Gene effects in corn (Zea mays L.). Separation and relative importance of gene effects for yield. Canadian Journal of Plant Science 42:339-348.

Griffing B (1956). Concept of general and specific combining ability in relation to diallel crossing systems. Australian Biological Science 9:463493.

Hallauer AR, Russell WA, Lammkey KR (1988). Corn breeding-corn and corn improvment. In: Sprague GF, Dudley JW (Eds). Corn and corn improvement. Third Edition, Am Soc of Agron, Madison, WI 18:463564.

Hallauer AR (1990). Methods used in developing maize inbreds. Maydica 35:1-16.

Hallauer AR, Carena MJ (2012). Recurrent selection methods to improve germplasm in maize. Maydica 57:266-283.

Haș I, Haș V, Mureșan E, Ifrim S (2010). Folosirea descompunerilor ortogonale și neortogonale în compararea unor grupe de genotipuri [Use of orthogonal and nonorthogonal decompositions in comparison of genotypegroups]. Analele INCDA Fundulea 78(2):5-16.

Haș V, Haș I, Chicinaș C, Șchiop T, Coste ID, Tritean N (2011). Valoarea fenotipică și genotipică a unor linii consangvinizate isonucleare de porumb [Phenotypic and genotypic value of some isonuclear corn inbred lines]. Analele INCDA Fundulea LXXIX:49-66.

HmielowskiT(2018). Maize yield potential. CSANews 63(3):8-9.

Malik S, Malika N, Mihas N, Munir M (2004). General and specific combining ability studies in maize diallel crosses. International Journal of Agriculture \& Biology 6(5):856-859.

Muntean L, Haş I, Haș V, Gulea A, Muntean S (2014). Combining ability for yield in maize synthetic populations obtained from local populations. Romanian Agricultural Research 31:3-10.

Murtadha MA, Ariyo OJ, Alghamdi SS (2018). Analysis of combining ability over environments in diallel crosses of maize (Zea mays). Journal of the SaudiSociety of Agricultural Sciences 17:69-78.

Ona $\mathrm{AD}$ (2014). Studiul fenotipic și genotipic al unor linii consangvinizate obținute din două composite heterotice de porumb (Zea mays L.) [Study on maize (Zea mays L.) phenotype and genotype in a series of inbred lines derived from two heterotic composites]. $\mathrm{PhD}$ Thesis, UASVMCluj-Napoca.

Owusu G, Nyadanu N, Obeng-Antwi G, Amoah R, Danso F, Amissah S (2017). Estimating gene action, combining ability and heterosis for grain yield and agronomic traits in extra-early maturing yellow maize singlecrosses under three agro-ecologies ofGhana. Euphytica 213:1-17.

Sarca T (2004). Ameliorarea porumbului. In: Porumbul - studiu monografic [Maize breeding. In: Maize - Monografic Study]. Ed. Academiei Române, Bucureștipp 363-449.

Souza LV, Miranda GV, Cardoso GalvaoJC, Moreira Guimaraes LJ, Santos IC (2009). Combining ability of maize grain yield under different levels of environmental stress. Pesquisa Agropecuaria Brasileira, Brasilia $44(10): 1297-1303$. 